\title{
Klasifikasi Topik Tugas Akhir Mahasiswa menggunakan Algoritma Particle Swarm Optimization dan K-Nearest Neighbor
}

\author{
Sumarni $^{\text {a.1,* }}$ dan Suhardi Rustam ${ }^{\text {a.2 }}$ \\ ${ }^{a}$ Universitas Ichsan Gorontalo, Jln. Achmad Najamuddin, Kota Gorontalo dan Kode Pos 96115, Indonesia \\ ${ }^{1}$ marnisiwa@gmail.com; ${ }^{2}$ suhardirstm@gmail.com \\ *corresponding author
}

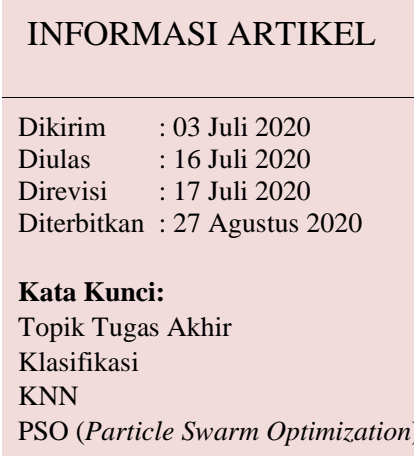

Keywords:

Topic of the Final Assignment

Classification

KNN

PSO (Particle Swarm Optimization)

\section{ABSTRAK}

Permasalahan Topik Tugas akhir merupakan suatu bentuk karya tulis ilmiah yang memuat hasil pengamatan dari suatu penelitian terhadap masalah yang terjadi dengan menggunakan metode yang berkaitan dengan bidang ilmu tertentu. Setiap mahasiswa disetiap program studi harus menyusun tugas akhir. Namun, sebelum memulai menulis tugas akhir, setiap mahasiswa harus mempunyai bidang topik sebagai tujuan, langkah pemilihan topik tugas akhir merupakan langkah awal sebelum mengerjakan tugas akhir. Salah satu cara untuk mendapatkan topik tugas akhir yaitu dengan melihat nilai mata kuliah umum serta mata kuliah kosentrasi jurusan, nilai yang mendominasi adalah nilah yang layak untuk cakupan topik penelitian. penilitian ini dilakukan penerapan metode K-Nearest Neighbor (KNN) untuk kategorisasi nilai mata kuliah kosentrasi untuk cakupan topik penelitian, topik seluruh nilai dalam dataset nantinya akan diklasifikasikan oleh KNN dan di optimasi dengan algoritma Particle swarm Optimization (PSO). Eksperimen kategorisasi tugas akhir ini dibangun dengan data latih Mahasiswa Universitas Ichsan Gorontalo yang telah diklasifikasikan sebelumnya dan data uji berasal dari seluruh nilai Mata Kuliah yang belum diketahui kategorinya. Hasil eksperimen, nilai akurasi yang dihasilkan algoritma KNN yaitu nilai akurasi terbaik dengan $\mathrm{K}=3$, K Folds $=10$ memiliki akurasi yaitu $72.46 \%$ dan Algoritma KNN-PSO akurasi terbaik dengan $\mathrm{K}=3$, K Folds $=10$ memiliki akurasi yaitu $89.86 \%$, ini menunjukan akurasi lebih baik dengan menggunakan algoritma optimasi

\section{ABSTRACT}

Problems the Topic of the final project is a form of scientific writing that contains the results of observations from a study of the problems that occur with the use of methods related to the particular field of science. Every student in every program of study must draw up a final project. However, before embarking on writing the final project, each student must have the topic area as a destination, the step of selection the topic of final project is an initial step before working on the final task. One way to get the final task is to see the value of general courses as well as courses, concentration majors, the value of which dominate the is is decent to scope the research topic. this research is conducted on the application of the method of K-Nearest Neighbor (KNN) for categorization of the value of the courses of concentration for the coverage of the research topic, topic the entire value in the dataset will be classified by $\mathrm{KNN}$ and in the optimization with the Particle swarm Optimization algorithm (PSO). The experimental categorization of the final project is built with the training data Mahasiswa Universitas Ichsan Gorontalo that has been classified previously and test data derived from the entire value of the courses is not yet known categories. The results of the experiments, the value of the resulting accuracy of algorithms $\mathrm{KNN}$, namely the value of the best accuracy with $\mathrm{K}=3$, K Folds $=10$ has an accuracy that is $72.46 \%$ and the Algorithm of KNN-PSO best accuracy with $\mathrm{K}=3$, K Folds $=10$ has an accuracy that is $89.86 \%$, shows the accuracy is better by using the optimization algorithm.

This is an open access article under the $\mathrm{CC}-\mathrm{BY}-\mathrm{SA}$ license.

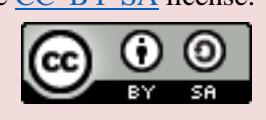




\section{Pendahuluan}

Melimpahnya Data Akademik yang dimiliki Universitas sebagai aset informasi yang akan berguna dalam pengelolaan akademik dan sebagai benefit value yang akan menguntungkan universitas. Data tersebut diantaranya tentang data akademik mahasiswa. Di bidang akademik, disetiap semester bertambahnya jumlah data yang direkan data dari kegiatan akademik seperti perekaman tugas mahasiswa, nilai mid, tugas tambahan mahasiswa dan nilai akhir semester mahasiswa dan sebagainya sehingga mengakibatkan tumpukan data dengan berbagai kapasitas, dengan meningkatnya volume penyimpanan pada situs dan server akademik universitas. Hal tersebut juga berlaku di Teknik Informatika Universitas Ichsan Gorontalo. TA(Tugas Akhir) merupakan bentuk penelitian yang dilakukan mahasiswa di akhir masa studi sebagai salah satu persyaratan untuk kelulusan mahasiswa tersebut. Namun tidak sedikit mahasiswa yang akan melaksanakan Tugas Akhir kesulitan dalam mencari topik Tugas Akhir yang sesuai dengan keahlian dan minat mahasiswa tersebut. Padahal ada banyak penelitian atau Tugas Akhir terdahulu yang dapat dikembangkan sebagai topik Tugas Akhir yang baru bagi mahasiswa. Dalam penelitian ini akan dirancang pengklasifikasian suatu dataset akademik yang dapat membantu mahasiswa-mahasiswa yang akan melaksanakan Tugas Akhir kuliah di Program Studi Teknik Informatika dan kemudian klasifikasi topik yang mungkin sesuai dengan minat dan keahlian dari mahasiswa tersebut. Rekomendasi dilakukan dengan hasil dari klasifikasi berdasarkan cakupan nilai akademik terdahulu yang dilakukan sebelumnya oleh mahasiswa Teknik Informatika Universitas Ichsan Gorontalo Dengan adanya data tersebut nantinya diharapkan dapat membantu mahasiswa yang akan melaksanakan Tugas Akhir untuk menemukan topik yang sesuai dengan keahlian dan minat mahasiswa, sehingga dapat mengurangi jumlah mahasiswa yang terlambat lulus dikarenakan sulit menemukan topik yang sesuai dengan minat dan keahlian mahasiswa.

Dataset akademik mahasiswa akan melalui proses pengolahan dari data menjadi pengetahuan ini disebut dengan istilah data mining. Data mining adalah disiplin ilmu yang mempelajari metode untuk mengekstrak pengetahuan atau menemukan pola dari suatu data yang besar. Pengetahuan yang dihasilkan dapat berupa pola, rumus, aturan atau model. Training data mining mempelajari bagaimana mengolah data menjadi pengetahuan menggunakan software data mining orange. Peserta akan mendapatkan banyak studi kasus penerapan Data Mining. Diharapkan setelah mengikuti training ini, peserta siap menghadapi tantangan kasuskasus pada penerapan data mining pada kehidupan nyata.

Sebagai algoritma optimasi digunakan Algoritma PSO (Particle Swarm Optimization) sebagai salah satu algoritma optimasi yang dapat digunakan untuk pengambilan keputusan. Tetapi bisa juga digunakan untuk pencarian jalur[1]. Contoh yang dibahas kali ini adalah mengenai pencarian posisi dengan pengembalian nilai fungsi minimal[2]. Particle Swarm Optimization[3] adalah teknik optimasi dengan cara menghitung secara terus menerus calon solusi dengan menggunakan suatu acuan kualitas. Adapun algoritma K-NN[4] merupakan metode untuk melakukan klasifikasi terhadap objek[5] berdasarkan data yang jaraknya paling dekat dengan objek tersebut[6], cara untuk mengukur jarak kedekatan antara data baru dengan data lama(data training)[7], diantaranya Euclidian distance [8]dengan menggunakan sampel-sampel dari data testing[9].

Pada penelitian akan menganalisis bagaimana mengoptimasi algoritma KNN dengan menggunakan algoritma PSO (Particle Swarm Optimization) dalam menentukan klasifikasi topik penelitian mahasiswa semester akhir dan bagaimana akurasi dari penggunaan optimasi dengan hasil optimal.

\section{Metode}

Metode eksperimen digunakan untuk penelitian ini, penggunaan cara penelitian eksperimen untuk tahap penelitian akan dimulai dari pengumpulan data sampai dengan mendapatkan hasil evaluasi dan hasil untuk mendapatkan tujuan yang akan dicapai, tahapan preprosessing sebagai tahap awal untuk mengidentifikasi missing value dan menghilangkan data yang tidak memiliki nilai[10], seperti pada Gambar 1 .

\section{A. Model Eksperimen}

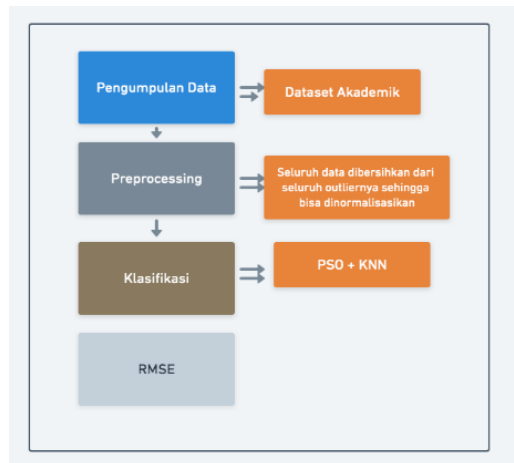

Gambar 1. Model Ekperimen KNN-PSO Validation 


\section{B. Pengumpulan Data}

Identifikasi variabel dari dataset di bagian pusat pengelolaan data akademik Universitas sebagai tahap awal sebagai cara dalam menentukan pengelolaan data dan proses analisisnya menggunakan alat analisis data[11]. Beberapa variabel yaitu seluruh mata kuliah kosentrasi yang terkait, nilai dari setiap mata kuliah dan nilai prestasi akademik. Adapun info data eksperimen dapat dilihat pada Tabel 1.

Tabel 1. Info data eksperimen

\begin{tabular}{lll}
\hline No & Nama Uraian & Deskripsi \\
\hline 1 & Dataset Data Akademik Mahasiswa & $\begin{array}{l}\text { Nama dataset yang berisi sekumpulan data yang siap digunakan } \\
\text { dalam eksperimen }\end{array}$ \\
\hline 2 & Dataset Size & Ukuran dataset dalam bentuk kolom dan baris \\
\hline 3 & Features & Model data yang akan diproses seperti kategori dan numerik \\
\hline 4 & Meta Atributt & $\begin{array}{l}\text { Variable dalam dataset yang akan dilewati dalam pemrosesan data } \\
\text { sepeti nim dan nama }\end{array}$ \\
\hline
\end{tabular}

\section{Pengolahan Data Awal}

Pada tahapan ini melakukan preprocessing terhadap data untuk menghilangkan outlier[12], melengkapi nilai setiap variabel yang terkait sehingga memiliki kesiapan dalam penggunaan alat analisis data. Adapun tahapan preprocessing dapat dilihat pada Gambar 2.

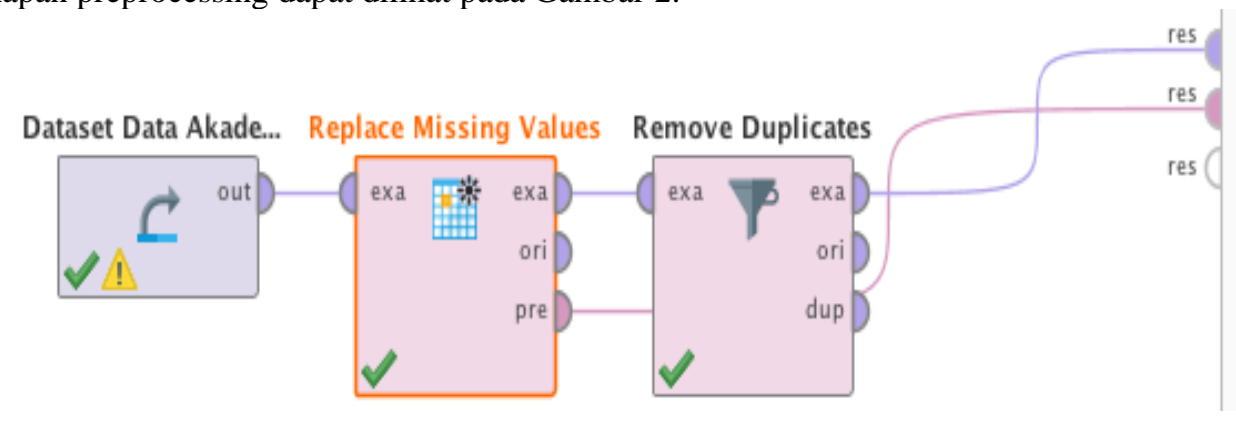

Gambar 2. Tahapan preprocessing

\section{Eksperimen}

Ekperimen pada tahapan ini adalah menjalan seluruh prosedur yang telah ditentukan/disusun dalam sebuah kerangka pemikirian untuk menyelesaikan masalah[13], adapun tahapannya adalah, di mulai dari penyiapan dataset kemudian dilakukan langkah prepossessing terhadap data untuk menghilangkan outliernya[14], selanjutnya adalah menormalisasikan data kemudian menggunakan tool rapidminer data mining untuk mengelola data tersebut[15] dengan menggunakan metode Optimasi dan KNN pada tahapan optimasi dan klasifikasi yang hasilnya akan di evaluasi dengan akurasi yang teroptimasi seperti pada Gambar 3 dan 4.
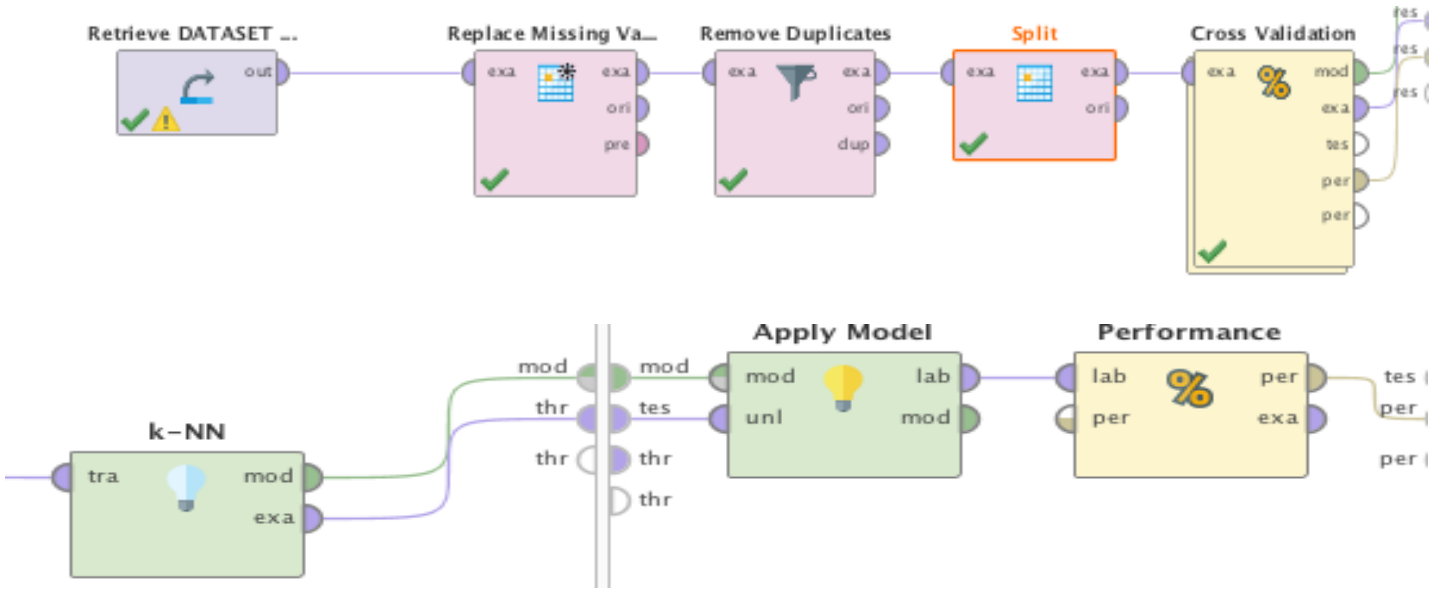

Gambar 3. Model KNN Validasi 


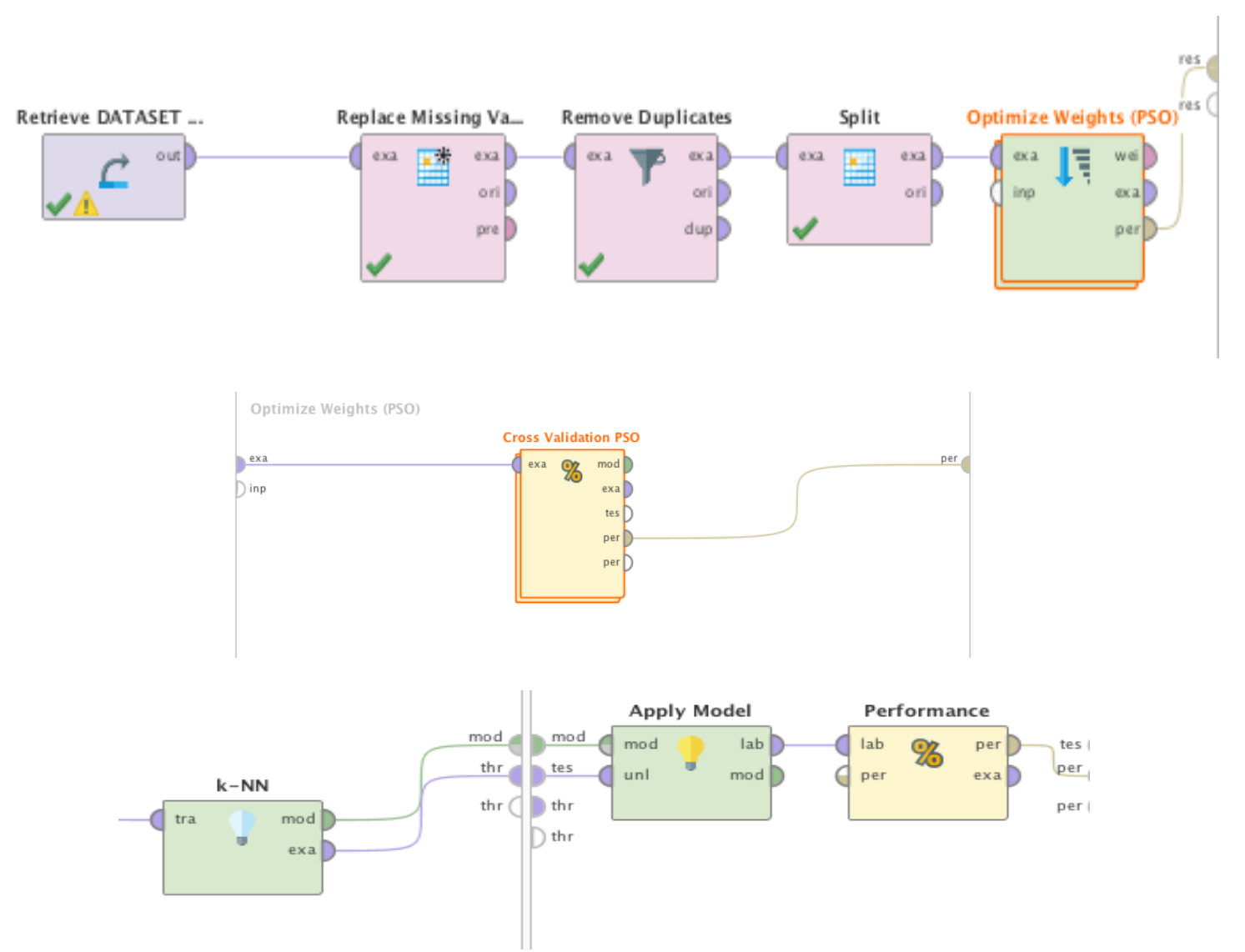

Gambar 4. Model Eksperimen KNN dengan Optimasi PSO

\section{E. Evaluasi}

Pada tahapan Pengujian eksperimen yang dilakukan pada algoritma KNN dan KNN-PSO serta eksperimen nilai akurasi pada algoritma optimasi tersebut[16].

\section{Hasil dan Pembahasan}

\section{A. Data Hasil Preprocessing}

Setelah melewati tahapan preprocessing, sebagian data tersebut ditampilkan pada Tabel 2.

Tabel 2. Hasil Preprocessing

\begin{tabular}{|c|c|c|c|c|c|c|c|c|c|c|c|c|c|c|c|c|c|c|}
\hline & A & B & c & D & E & $\mathrm{F}$ & G & H & 1 & 1 & к & L & M & $\mathrm{N}$ & o & $\mathrm{p}$ & a & $\mathrm{R}$ \\
\hline & NIM & Nama & Kelamin & MKUJI & MKLOGIKON & MKELEARN & MKEGOV & KRPL & MKDATA & MKSTRUKTUI & KJARKOM & MKKOMLAN.I & MKDIGITAL & PROJECT & FRAMEW & MKMGMNT & MOBILE & E Lat \\
\hline & T3116032 & RANDIS BAI & & 0,13819444 & 4 & 02.52 & 0,10277778 & 03.36 & 03.07 & 03.06 & 03.06 & 4 & 03.07 & 03.06 & 03.06 & 4 & 03.07 & 07 FRAMEWC \\
\hline & T3116309 & GISKA PUTRI & & 0,17152778 & & 0,17638889 & 0,17152778 & 03.29 & 4 & 03.07 & 03.09 & 4 & 4 & 03.07 & 03.07 & 4 & & 4 FRAMEWORK \\
\hline & T3116310 & MUHAMADI & & 0,17152778 & 03.06 & 0,17013889 & 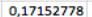 & 4 & 4 & 03.07 & 03.07 & 03.06 & & 03.07 & 03.07 & 03.06 & & 4 FRAMEWORK \\
\hline & T3116312 & DWI UMMU & & 0,17708333 & 03.09 & & 0,18611111 & 4 & 03.06 & 4 & 03.09 & 03.09 & 03.07 & 4 & 4 & 03.09 & & 06 FRAMEWORK \\
\hline & T3116314 & ISMAIL M. S, & & & 03.07 & 0,17638889 & 0,18611111 & 03.54 & 4 & 4 & 4 & 03.07 & 4 & 4 & 4 & 03.07 & & 4 FRAMEWORK \\
\hline & T3116315 & AMRIN PAPE & & 0,17152778 & 03.09 & 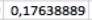 & 0,16875 & 0,17986111 & 4 & 03.07 & 03.07 & 03.09 & & 03.07 & 03.07 & 03.09 & & 4 FRAMEWORK \\
\hline & T3116316 & NADIRA & P & 0,17708333 & 03.06 & & 0,18611111 & & 4 & 4 & 4 & 03.06 & 03.06 & 4 & 4 & 03.06 & & 4 FRAMEWORK \\
\hline & T3116317 & SAFRIN HUN & & 0,17152778 & 03.06 & 0,18541667 & 0,18611111 & 0,17430556 & 03.06 & 4 & & 03.06 & & & 4 & 03.06 & & 06 FRAMEWORK \\
\hline & T3116318 & ALWIN Y. LA & & 0,17708333 & 03.07 & 0,17013889 & 0,18611111 & 03.54 & 03.09 & 03.06 & 03.06 & 03.07 & 4 & 03.06 & 03.06 & 03.07 & 03.09 & \\
\hline & T3116319 & NOVIYANTII & & 03.54 & 03.07 & 0,18541667 & 0,17708333 & & 3.07 & 4 & 4 & 03.07 & 4 & 4 & 4 & 03.07 & 03.07 & 07 FRAMEWORK \\
\hline & T3116320 & ELA M. PATIU & & 0,17708333 & & 0,17013889 & 0,17708333 & 03.54 & 03.09 & 4 & 4 & 4 & 03.06 & 4 & 4 & 4 & 03.09 & 09 FRAMEWORK \\
\hline & T3116321 & ARRIJAL MU & & & & 0,17916667 & 0,17708333 & 02.05 & 03.06 & 4 & 4 & 4 & 03.09 & 4 & 4 & 4 & 03.06 & 06 FRAMEWORK \\
\hline & $\begin{array}{l}\text { T3116323 } \\
T_{T} 13116324\end{array}$ & $\begin{array}{l}\text { RENALDI TUI } \\
\text { SUSANO P }\end{array}$ & & $\begin{array}{l}0,17152778 \\
1,17023233\end{array}$ & 03.07 & 0,17916667 & $\begin{array}{r}0,16875 \\
\end{array}$ & 03.42 & 03.06 & 03.06 & 03.06 & 03.07 & 03.07 & 03.06 & 03.06 & 03.07 & 03.06 & 06 FRAMEWORK \\
\hline & $\begin{array}{l}\text { T3116324 } \\
\text { T3116325 }\end{array}$ & $\begin{array}{l}\text { SUSANTO PA } \\
\text { RAHMAT MA }\end{array}$ & & 0,17708333 & & $\begin{array}{l}0,18541667 \\
0176388989\end{array}$ & 0,17708333 & & 03.07 & 03.09 & 03.09 & $\begin{array}{r}4 \\
0307\end{array}$ & 03.09 & 03.09 & 03.09 & 4 & 03.07 & 07 FRAMEWORK \\
\hline & 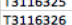 & $\begin{array}{l}\text { RAHMAT MA } \\
\text { FIKRAM YUN }\end{array}$ & & $\begin{array}{l}0.3 .05 \\
0.33\end{array}$ & $\begin{array}{r}4 \\
03.06\end{array}$ & $\left\{\begin{array}{l}0,17638889 \\
0,17013889\end{array}\right.$ & $\begin{array}{l}03.54 \\
03.17 \\
0.0\end{array}$ & $\begin{array}{l}03.05 \\
03.21\end{array}$ & $\begin{array}{l}03.07 \\
4\end{array}$ & $\begin{array}{l}03.07 \\
03.09\end{array}$ & $\begin{array}{l}03.07 \\
03.09\end{array}$ & $\begin{array}{ll}03.07 \\
4\end{array}$ & $\begin{array}{l}03.06 \\
03.06\end{array}$ & $\begin{array}{l}03.07 \\
03.09\end{array}$ & $\begin{array}{l}03.07 \\
03.09\end{array}$ & 4 & 03.07 & 07 FRAMEWORK \\
\hline & T3116327 & MOH AFFAN & & 0,17708333 & & 0,17013889 & 0,17708333 & \begin{tabular}{|l|l|} 
\\
\end{tabular} & 4 & 4 & 4 & 4 & 03.07 & ( & 4 & 4 & & $\begin{array}{l}4 \text { FRAMEWORK } \\
4 \text { FRAMEWRK }\end{array}$ \\
\hline & T3116328 & WAHYU AKB & & 0,14444444 & & 0,17013889 & 03.42 & 0,17986111 & 03.07 & 03.07 & 4 & 03.07 & 03.07 & 03.07 & 03.07 & & & 07 FRAMEWORK \\
\hline & T3116329 & NELVA PALII & & 0,17708333 & 4 & & 0,17708333 & 0,17986111 & 4 & 4 & .06 & 4 & 4 & 4 & 4 & 4 & & 4 FRAMEWORK \\
\hline & T3116330 & DELVIANA D, & & & 06 & 0,16736111 & 03.42 & 03.42 & 4 & 4 & & 4 & 4 & 4 & 4 & & & wORK \\
\hline & T3116332 & yayu & & 0,17708333 & 09 & & 0,17708333 & 03.42 & 03.06 & 03.06 & .07 & 03.06 & 03.07 & 03.06 & 03.06 & 03.09 & & 06 FR \\
\hline & T3116333 & MAIM & & 0,17708333 & .07 & & 0,18611111 & & 4 & 4 & 03.09 & 4 & 4 & 4 & 4 & 03.07 & & WORK \\
\hline & T3116335 & ALAN & & 03.25 & & 0,17013889 & & 08 & 4 & 4 & & 4 & 4 & 4 & 4 & 03.09 & & $4 \mathrm{FR}$ \\
\hline & T3116338 & FEBRI & & 0,17708333 & & 0,17013889 & 0,17708333 & 03.46 & 4 & 4 & 03.06 & 4 & 03.06 & 5 & 4 & 4 & & 4 FRAMEWORK \\
\hline & $\begin{array}{l}\text { T3116339 } \\
\text { T3116599 }\end{array}$ & TRIHARDIYA| & & 0,16875 & 03.06 & & 0,17708333 & 0,16875 & .06 & .06 & 03.07 & .06 & 4 & 03.06 & 03.06 & 03.06 & 03.06 & 06 FRAMEWORK \\
\hline 27 & $\begin{array}{l}\text { T3116359 } \\
\end{array}$ & $\begin{array}{l}\text { ANDIKA HUR } \\
\text { A ANDY UMA }\end{array}$ & & 03.54 & 03.09 & $\begin{array}{l}0,17638889 \\
0,17916567\end{array}$ & 0,17708333 & 4 & 03.09 & 03.09 & 03.07 & 03.09 & 4 & 03.09 & 03.09 & 03.09 & 03.09 & O9 FRAMEWORK \\
\hline 29 & $\begin{array}{l}\text { T31116660 } \\
\text { T3116361 }\end{array}$ & FANDY UMA & & $\begin{array}{l}02.58 \\
708333\end{array}$ & 03.07 & $\begin{array}{l}0,17916667 \\
0.18541657\end{array}$ & $\begin{array}{r}03.54 \\
0.18611111\end{array}$ & 03.04 & 03.07 & 03.07 & 4 & 03 & & 3.07 & 07 & 03.07 & & 07 FRAMEWORK \\
\hline & T3116363 & ANSAR & L & $\begin{array}{l}0,17778083333 \\
0,1733\end{array}$ & 4 & $\mid \begin{array}{l}0,1854466 \\
0,17638889\end{array}$ & $\begin{array}{l}\mid, 018611111 \\
0,18611111\end{array}$ & $\begin{array}{l}4 \\
4\end{array}$ & $\begin{array}{l}03.09 \\
03.06\end{array}$ & 99 & 03.07 & 03.06 & 03.09 & 09 & 4 & 4 & 03.06 & O6 ELEARNING \\
\hline 31 & T3116364 & RIZAL TUI & L & 03.23 & 4 & 0,17013889 & 0,17708333 & 3 & 4 & 4 & 4 & 03.06 & 03.07 & 7 & 4 & 4 & & 4 ELEARNING \\
\hline
\end{tabular}




\begin{tabular}{|c|c|c|c|c|c|c|c|c|c|c|c|c|c|c|c|c|c|}
\hline & 07 & NADMA DS.PP & 0,1861111 & 03.07 & 03.06 & 4 & 0.1 & & 03.06 & 4 & 03.07 & 09 & 03.06 & 03.06 & 3.07 & & ELEARNING \\
\hline 33 & T3117209 & NOVAL KURY L & 0,1861111 & & 03.07 & 4 & 0,1861111 & 03.06 & 03.09 & 4 & 03.07 & 03.06 & 03.09 & 03.09 & & & ELEARNING \\
\hline 34 & T3117210 & AMINARTIM P & 0,1861111 & 4 & 4 & 4 & 0,1861111 & 03.09 & 03.07 & & & 03.09 & 03.07 & 03.07 & & 03.09 & \\
\hline 35 & T3117211 & SUSANTI LAH P & 0,1861111 & 03.06 & 4 & 4 & 0,1861111 & 03.07 & 03.09 & 03.09 & 4 & 03.06 & 03.09 & 03.09 & 03.06 & 03.07 & ELEARNING \\
\hline 36 & T3117212 & NURWINDIP P & 0,1861111 & 4 & 4 & 4 & 0,1861111 & 03.09 & 03.06 & 03.07 & .07 & 03.06 & 03.06 & 03.06 & 4 & & \\
\hline 37 & \begin{tabular}{|l} 
T3117214 \\
T3117215
\end{tabular} & $\begin{array}{l}\text { SILVANAIIRR P P } \\
\text { SRINDRYN }\end{array}$ & 0,1861111 & $4^{4}-1$ & $0^{4}$ & 4 & 0,1861111 & 03.06 & 03.06 & 03.09 & $4^{4}-1$ & 03.07 & 03.06 & 03.06 & $4^{4}-3$ & 03.06 & ELEARNING \\
\hline $\begin{array}{l}38 \\
39\end{array}$ & $\begin{array}{l}T 3117215 \\
3117216\end{array}$ & $\begin{array}{l}\text { SRI INDRAYAN P } \\
\text { JUMALIN S L }\end{array}$ & & 0306 & $\begin{array}{l}03.06 \\
03.15\end{array}$ & $\begin{array}{r}44 \\
0.42\end{array}$ & 0,1861111 & $\begin{array}{l}03.06 \\
0307\end{array}$ & $\begin{array}{l}03.07 \\
03.07\end{array}$ & $\begin{array}{l}03.06 \\
0306\end{array}$ & 0306 & 03.07 & $\begin{array}{l}03.07 \\
0307\end{array}$ & 0307 & 0306 & $\begin{array}{l}03.06 \\
0307\end{array}$ & $\begin{array}{l}\text { ELEARNANG } \\
\text { ELEARNING }\end{array}$ \\
\hline 40 & T3117217 & IKHSAN YUN L & 0,1743056 & 03.09 & 03.06 & 0,18611111 & 0,1861111 & 03.07 & 4 & 03.07 & 4 & ${ }_{4}^{4}$ & 4 & 4 & 03.09 & 03.07 & $\begin{array}{l}\text { ELEARNING } \\
\text { ELARNG }\end{array}$ \\
\hline 41 & T3117218 & HENDRO PRUL & & 03.07 & 03.09 & 0,1770833 & & & & 03.07 & 4 & 03.07 & & & 03.07 & & ELEARNING \\
\hline${ }_{43}^{42}$ & $\begin{array}{l}T 3117219 \\
T 31720\end{array}$ & IRMAWATIL. P & 0,1861111 & 03.09 & 4 & 4 & 0.1861111 & $\begin{array}{r}4 \\
0.307\end{array}$ & 03.07 & 4 & 0305 & & 03.07 & 03.07 & 03.09 & 4 & $\begin{array}{l}\text { ELARARING } \\
\text { FRAM }\end{array}$ \\
\hline 44 & T31172222 & $\begin{array}{l}\text { ANGGRAN NIE } L \\
\text { WIKA }\end{array}$ & 0 & & 03.49 & 0,1861111 & $\begin{array}{l}0.18611111 \\
0,1861111\end{array}$ & $\begin{array}{r}03.07 \\
4\end{array}$ & ${ }_{4}^{4}$ & $\begin{array}{r}4 \\
0307\end{array}$ & $\begin{array}{l}3.306 \\
0.309\end{array}$ & 0.44 & $\begin{array}{l}4 \\
4\end{array}$ & 4 & & & $\begin{array}{l}\text { FRAMWORK } \\
\text { FRAMEWORK }\end{array}$ \\
\hline 45 & T3117223 & ABDUL MAR L & 0,1861111 & 4 & 4 & 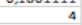 & 0,1861111 & 4 & 4 & 4 & 03.07 & 4 & 4 & 4 & ${ }_{4}^{4}$ & & FRAMEWORK \\
\hline 46 & T3117224 & SINDRIWATI P & 0,1861111 & 03.06 & 4 & & 0,1861111 & 4 & 03.06 & 3.07 & 03.09 & 4 & 03.06 & 03.06 & & & AAMEWWORK \\
\hline & T3117225 & ROCKY USM L L & 0,1715278 & 03.09 & 03.06 & 0,1861111 & 0,1861111 & 03.06 & 03.09 & 4 & 03.06 & 4 & 03.09 & 03.09 & 03.09 & 03.06 & FRAMEWORK \\
\hline 48 & T3117226 & JEREMI & 0,1743056 & 03.07 & 03.06 & 0,1861111 & 0.1861111 & 03.09 & 03.07 & & 4 & 03.06 & 03.07 & 03.07 & 03.07 & 03.09 & FRAMEWORK \\
\hline & [T3117227 & REFSIGUGE L & 03.58 & 03.09 & 03.06 & 0,1861111 & 0.1861111 & 03.07 & 03.09 & 03.06 & 4 & 03.09 & 03.09 & 03.09 & 03.09 & 03.07 & FRAMEWORK \\
\hline & T3117228 & SUSANTY L.P P P & 1798611 & 03.06 & & & 0.1861111 & 03.09 & 03.06 & 4 & 03.06 & 03.07 & 03.06 & 03.06 & 03.06 & 03.09 & FRAMEWORK \\
\hline & T3117230 & RESKII & 0,1861111 & 03.06 & & & 1111 & 03.06 & 03.06 & $4^{4}-3$ & 03.09 & 03.09 & 03.06 & 03.06 & 03.06 & 03.06 & FRAMEWORK \\
\hline${ }_{5}^{52}$ & | & MUHAMADIL & 0,1798611 & 03.07 & $\begin{array}{r}0,17708333 \\
0309\end{array}$ & 0,1861111 & 0,1861111 & 03.06 & 03.077 & 4 & 03.07 & 03.06 & 年3.07 & 03.077 & 03.07 & 03.06 & $\begin{array}{l}\text { FRAMWORK } \\
\text { FRAMWORK }\end{array}$ \\
\hline 54 & T3117233 & RAFLIN MUS L & 0 & & 03.06 & $0,0,1861111$ & $\begin{array}{l}0,18611111 \\
0,1861111\end{array}$ & 03.07 & 4 & 03.09 & 03.06 & 4 & 4 & 4 & 4 & 03.07 & FRAMEWORK \\
\hline 55 & T3117234 & RAFIL & 0,1861 & 4 & 03.07 & 1111 & 0. & 4 & 4 & 03.07 & 03.06 & 03.07 & 4 & 4 & 4 & & FRAMEWORK \\
\hline 56 & T3117235 & & 03.58 & 03.07 & 03.07 & 0,1861111 & 0,1 & 4 & 03.07 & 03.09 & 03.07 & 4 & 03.07 & 03.07 & 03.07 & & FRAMEWORK \\
\hline $\begin{array}{l}57 \\
58\end{array}$ & $\begin{array}{l}73117236 \\
3117337\end{array}$ & $\begin{array}{l}\text { ASNUN S.LANP } \\
\text { DIAFAR DDA }\end{array}$ & 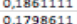 & 4 & 4 & 0,1861111 & 0,1861111 & 03.07 & 4 & 03.06 & 03.07 & $4^{4}$ & 4 & 4 & 4 & 03.07 & $\begin{array}{l}\text { ELEARNING } \\
\text { FRAMWOPK }\end{array}$ \\
\hline 59 & T3117238 & VEYBE MEYS* P & 0,1861111 & 4 & 03.07 & 0,1861111 & 0,1861111 & 4 & 4 & 4 & 4 & 4 & 4 & 4 & ${ }_{4}^{4}$ & & FRAMEWORK \\
\hline 60 & & & 11 & 03.06 & & 0,1861111 & 0,186 & 4 & 03.07 & 03.06 & 03.07 & 4 & & 03.07 & 03.06 & & FRAMEWORK \\
\hline 61 & T3117240 & Dan & 0,1861111 & 03.09 & 4 & 0,1861111 & 0,1861111 & 03.06 & 4 & 03.09 & 4 & 4 & 4 & 4 & 03.09 & 03.06 & ELEARNING \\
\hline 62 & T3117241 & ARDA & 0,1861111 & 03.07 & 03.06 & 0,1861111 & 0,1861111 & 03.09 & & 03.07 & 03.07 & 03.06 & 4 & & 03.07 & 03.09 & FRAM: \\
\hline 63 & T3117242 & RISKA & 0,1743056 & 03.09 & 4 & 0.1861111 & 0,18 & 03.07 & 03.06 & 0 & 4 & 03.09 & 03.06 & 03.06 & 03.09 & 03.07 & FRAMEWORK \\
\hline 54 & T3117243 & ZULHA & 03.21 & 03.06 & 4 & & 0,1861111 & 03.09 & 4 & 03.06 & 4 & 03.07 & 4 & 4 & 03.06 & 03.09 & FRAMEWORK \\
\hline & 44 & & 11 & 03.06 & & 0,1861111 & & 03.06 & & 03.06 & & 03.09 & ${ }^{4}$ & 4 & 03.06 & 03.06 & ELEARNING \\
\hline 60 & 年 & (N) & (3) & - & - & & 0 & 3.030 & 4 & - & 4 & - & 4 & 40 & - & - & \\
\hline 68 & T3117255 & 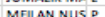 & 8 & 4 & 03.07 & $38->>$ & 0 & 0307 & 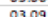 & 4 & 0305 & 4 & 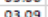 & 0.309 & 4 & (7) & $\begin{array}{l}\text { NORK } \\
\text { NORK } \\
\text { Not }\end{array}$ \\
\hline 69 & 252 & AL & 1 & 4 & 03.09 & 1861111 & 0 & 4 & 7 & 4 & 4 & 4 & 27 & $07 \quad>>1$ & 4 & & \\
\hline & T3117391 & FAISAL B.AB, L & 0,1743056 & 03.07 & 03.06 & 0.1861111 & 0.1861111 & 4 & 03.09 & 03.07 & 4 & 03.06 & 03.09 & 03.09 & 3.07 & & FRAMEWORK \\
\hline
\end{tabular}

\section{B. Algortma KNN Validasi}

Dalam memproses dataset dengan menggunakan model KNN menghasilkan klasifikasi yaitu Topik Framework dan Topik Elearning diperlihatkan pada pada Gambar 4. ExampleSet

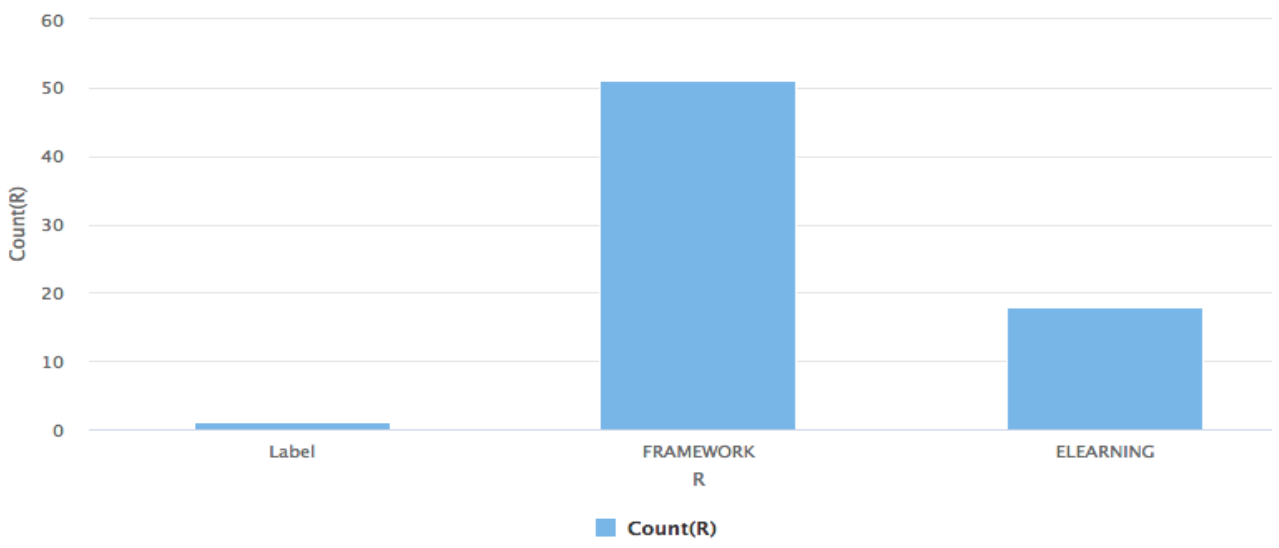

Gambar 4. Grafik Frekuensi Klasifikasi

Hasil eksperimen data akademik menggunakan algoritma KNN Validasi dapat dilihat pada Tabel 3.

Tabel 3. Hasil Eksperimen dengan KNN Validation

\begin{tabular}{llll}
\hline Algoritma & & Kriteria & Akurasi \\
\hline KNN & K & K Folds & \\
\hline 3 & 10 & $72.46 \%$ \\
\hline & 4 & 10 & $72.46 \%$ \\
\hline & 5 & 10 & $71.02 \%$
\end{tabular}

Hasil eksperimen KNN Validation dengan kriteria adalah untuk $\mathrm{K}=3$, $\mathrm{K}$ Folds $=10$, Akurasinya = $72.46 \%$, untuk $\mathrm{K}=4, \mathrm{~K}$ Folds $=10$, Akurasinya $=72.46 \%$, dan untuk $\mathrm{K}=5, \mathrm{~K}$ Folds $=10$ memiliki Akurasi $71.01 \%$, sehingga dari Tabel 3 akurasi terbaik dengan $\mathrm{K}=3$, K Folds $=10$ memiliki akurasi yaitu $72.46 \%$

\section{Algoritma KNN-PSO Validasi}

Eksperimen ini data yang digunakan adalah data dari hasil KNN Preprocessing dengan Model KNN Validation yang ditambahkan kedalam Operator Algoritma PSO sehingga KNN akan dioptimasi dengan algoritma PSO Validatioan, dengan hasil diperlihatkan pada Tabel 4. 
Tabel 4. Data Hasil KNN-PSO Validation

\begin{tabular}{llll}
\hline Algoritma & & Kriteria & Akurasi \\
\cline { 1 - 2 } & K & K Folds & \\
\hline & 3 & 10 & $89.86 \%$ \\
\hline & 4 & 10 & $86.96 \%$ \\
\hline & 5 & 10 & $71.01 \%$ \\
\hline
\end{tabular}

Hasil eksperimen KNN-PSO Validation dengan kriteria adalah untuk K=3, K Folds = 10, Akurasinya $=89.86 \%$, untuk $\mathrm{K}=4, \mathrm{~K}$ Folds $=10$, Akurasinya $=86.96 \%$, dan untuk K=5, K Folds $=10$ memiliki Akurasi $71.01 \%$, sehingga dari tabel 4.3 akurasi terbaik dengan $\mathrm{K}=3$, K Folds $=10$ memiliki akurasi yaitu $89.86 \%$.

D. Distribusi data hasil $\mathrm{KNN}$ dengan $\mathrm{K}=2$

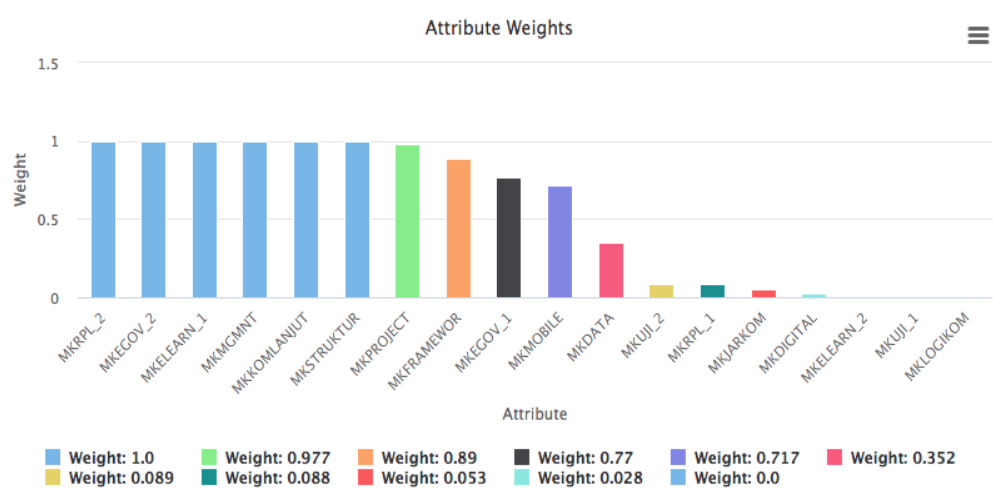

Gambar 6. Grafik Optimize Weights (PSO)

Gambar 6 sebagai gambaran data dari model Optimize Weights (PSO) adalah bobot yang dimiliki setiap atribut setiap dataset pada Akademik Mata Kuliah dalam menentukan klasifikasi Topik Penelitian Mahasiswa semester akhir

E. Akurasi data hasil Kmeans KNN dan KNN-PSO Validasi dimana K=3

Model klasifikasi dengan KNN Validation dan KNN-PSO Validation untuk K=3, K Folds = 10 dengan hasil eksperimen yang dapat dilihat pada Tabel 5 dan Gambar 7.

Tabel 5. Data Hasil KNN dan KNN-PSO Validation

\begin{tabular}{|c|c|c|c|}
\hline Algoritma & & Griteria & Akurasi \\
\hline KNN Validation & $\mathrm{K}$ & K Folds & \\
\hline & 3 & 10 & $72.48 \%$ \\
\hline KNN-PSO Validation & 3 & 10 & $89.86 \%$ \\
\hline
\end{tabular}

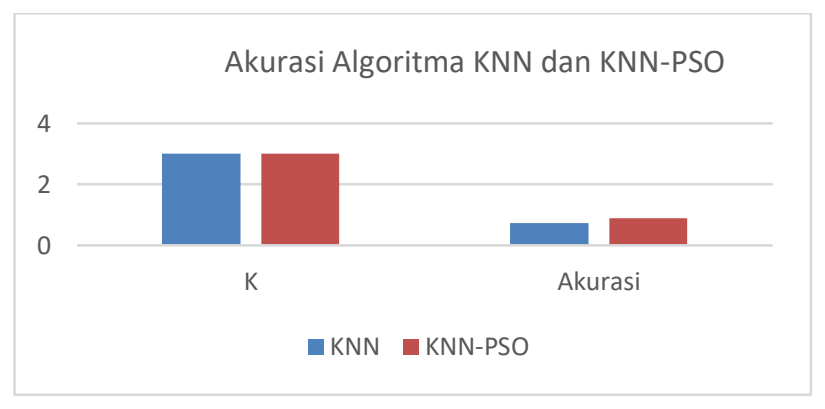

Gambar 7. Grafik Akurasi Algoritma KNN dan KNN-PSO 
F. Pembahasan hasil eksperimen KNN Validation dan KNN-PSO Validation, $K=3$

Hasil eksperimen yang telah dilakukan dengan menggunakan dataset akademik mahasiswa dengan 70 record data, 14 atribut dan 1 label digunakan untuk menentukan topik penelitian yang diawali dengan Teknik preprosesing untuk memberisihkan outlier/missing value pada setiap atribut yang ada dalam dataset. Pada eksperimen ini, tahapan pemodelan dengan menggunakan algoritma KNN sebagai tahapan pertama, tahapan kedua dengan menggunkanan Algoritma PSO (Particle Swarm Optimization) untuk mengoptimasi model tahap awal. Pemodelan dengan dengan menggunakan algoritma KNN Validasi dan juga pemodelan optimasi yaitu KNN-PSO Validasi.

Hasil eksperimen KNN Validation dengan kriteria adalah untuk $\mathrm{K}=3, \mathrm{~K}$ Folds $=10$, Akurasinya $=$ $72.46 \%$, untuk $\mathrm{K}=4$, $\mathrm{K}$ Folds $=10$, Akurasinya $=72.46 \%$, dan untuk $\mathrm{K}=5$, K Folds $=10$ memiliki Akurasi $71.01 \%$, sehingga dari tabel 4.2 akurasi terbaik dengan $\mathrm{K}=3$, K Folds $=10$ memiliki akurasi yaitu $72.46 \%$.

Pemodelan tahap kedua yaitu hasil eksperimen KNN-PSO Validation dengan kriteria adalah untuk $\mathrm{K}=3, \mathrm{~K}$ Folds $=10$, Akurasinya $=89.86 \%$, untuk $\mathrm{K}=4, \mathrm{~K}$ Folds $=10$, Akurasinya $=86.96 \%$, dan untuk $\mathrm{K}=5$, $\mathrm{K}$ Folds $=10$ memiliki Akurasi $71.01 \%$, sehingga akurasi terbaik dengan $\mathrm{K}=3$, K Folds $=10$ memiliki akurasi yaitu $89.86 \%$.

\section{Kesimpulan dan Saran}

Hasil eksperimen dalam uraian pembahasan penelitian ini, dapat disimpulkan bahwa penerapan algoritma KNN dan Algoritma KNN-PSO, PSO (Particle Swarm Optimization) sebagai algoritma optimasi terhadap algoritma KNN, dimana $\mathrm{K}=3$ mengahasilkan klasifikasi topik penelitian mahasiswa semester akhir dan masing-masing klasifikasi di validasi dan memiliki nilai akurasi prediksi untuk kedua pemodelan validasi tersebut dan nilai Akurasi yang dihasilkan Algoritma $\mathrm{KNN}$ yaitu nilai akurasi terbaik dengan $\mathrm{K}=3$, $\mathrm{K}$ Folds = 10 memiliki akurasi yaitu $72.46 \%$ dan Algoritma KNN-PSO akurasi terbaik dengan K=3, K Folds $=10$ memiliki akurasi yaitu $89.86 \%$

\section{Terima Kasih}

Terima kasih kepada Lembaga Penelitian (LEMLIT) Universitas Ichsan Gorontalo yang telah membantu penelitian kami.

\section{Daftar Pustaka}

[1] M. A. Banjarsari., I. Budiman, \& A. Farmadi. "Penerapan K-Optimal Pada Algoritma KNN Untuk Prediksi Kelulusan Tepat Waktu Mahasiswa Program Studi Ilmu Komputer Fmipa Unlam". Klik Kumpulan Jurnal Ilmu Komputer, 2(2), 159-173. 2016. https://doi.org/10.20527/KLIK.V2I2.26

[2] L. Dey, S. Chakraborty, A. Biswas, B. Bose, \& S. Tiwari. "Sentiment Analysis of Review Datasets Using Naïve Bayes' and K-NN Classifier". International Journal of Information Engineering and Electronic Business. 2016. https://doi.org/10.5815/ijieeb.2016.04.07.

[3] S. B. Imandoust and M. Bolandraftar, "Application of K-Nearest Neighbor (KNN) Approach for Predicting Economic Events: Theoretical Background," vol. 3, no. 5, pp. 605-610, 2013.

[4] M. E. Lasulika, "Prediksi harga komoditi jagung menggunakan K-NN dan Particle Swarm Optimazation," vol. 9, pp. 233-238, 2017.

[5] S. Y. Pandie. "Emerensye, Implementasi Algoritma Data Mining K-Nearest Neighbor (K-NN) Dalam Pengambilan Keputusan Pengajuan Kredit”. Seminar Nasional Sains dan Teknik, Kupang. 2012

[6] H. He, \& C. Alippi. Conference report for 2014 IEEE symposium series on computational intelligence (IEEE SSCI 2014) [Conference Reports]. IEEE Computational Intelligence Magazine, 10(2), 10-12. https://doi.org/10.1109/MCI.2015.2405273

[7] R. N. Whidhiasih, N. A. Wahanani and S. Supriyanto, "Klasifikasi buah belimbing berdasarkan citra Red-Greenblue menggunakan KNN dan LDA", Jurnal Penelitian Ilmu Komputer, System Embedded \& Logic 1(1): 29-35, 2013

[8] S. I. Bafandeh, dkk, "Application of K-Nearest Neighbor (KNN) Approach for Predicting Economic Events": Theoretical Background, S.B Imandoust et al. Int. Journal of Engineering Research and Applications. Vol. 3, Issue 5, 2013

[9] D. Kurniawan, W. Wibowo, \& P. Y. Astuti. "Pemanfaatan Educational Data Mining (Edm) Untuk Memprediksi Masa Studi Mahasiswa Menggunakan Algoritma C4.5 (Studi Kasus: TI-S1 Udinus)". Momentum, 12, 48-52. 2007a.

[10] D. Kurniawan, W. Wibowo, \& P. Y. Astuti. "Pemanfaatan Educational Data Mining (Edm) Untuk Memprediksi Masa Studi Mahasiswa Menggunakan Algoritma C4.5 (Studi Kasus: TI-S1 Udinus)". Momentum. 2007b. 
[11] G. I. Marthasari. "Implementasi Teknik Data Mining untuk Evaluasi Kinerja Mahasiswa Berdasarkan Data Akademik". Fountain of Informatics Journal, 2(2), 20. 2017 https://doi.org/10.21111/fij.v2i2.1216

[12] M. S. Mustafa, \& I. W. Simpen. Perancangan Aplikasi Prediksi Kelulusan Tepat Waktu Bagi Mahasiswa Baru dengan Teknik Data Mining (Studi Kasus: Data Akademik Mahasiswa STMIK Dipanegara Makassar). Creative Information Technology Journal, 1(4), 270. 2015. https://doi.org/10.24076/citec.2014v1i4.27

[13] A. Rohman. "Model Algoritma K-Nearest Neighbor (K-Nn) Untuk Prediksi Kelulusan Mahasiswa". Neo Teknika, 1(1). 2015. https://doi.org/10.1017/CBO9781107415324.004

[14] S. Rustam, H. A. Santoso, \& C. Supriyanto. "Optimasi K-Means Clustering Untuk Identifikasi Daerah Endemik Penyakit Menular Dengan Algoritma Particle Swarm Optimization Di Kota Semarang”. ILKOM Jurnal Ilmiah, 10(3), 251. 2018. https://doi.org/10.33096/ilkom.v10i3.342.251-259

[15] J. Han, Data Mining: Concepts and Techniques (The Morgan Kaufmann Series in Data Management Systems). 2011.

[16] G. I. Marthasari, "Implementasi Teknik Data Mining untuk Evaluasi Kinerja Mahasiswa Berdasarkan Data Akademik," Fountain Informatics J., vol. 2, no. 2, p. 20, 2017. 